\title{
Combining Ability Studies for Yield and Yield Contributing Traits in Garden Pea (Pisum sativum L.)
}

\author{
B. Manjunath ${ }^{1^{*}}$, Devaraju $^{1}$, V. Srinivasa ${ }^{1}$, M. Hanumantappa ${ }^{2}$, \\ D. Lakshmana ${ }^{3}$ and T. S. Aghora ${ }^{1}$
}

${ }^{1}$ Department of Vegetable Science, ${ }^{2}$ Department of Agronomy, ${ }^{3}$ Department of Genetics and plant breeding, College of Horticulture, Mudigere, Karnataka, India

*Corresponding author

\section{A B S T R A C T}

\begin{tabular}{l} 
Ke y w or d s \\
$\begin{array}{l}\text { Garden pea, } \\
\text { Combining ability, } \\
\text { L } \times \text { T mating } \\
\text { design, Gene action }\end{array}$ \\
Article Info \\
$\begin{array}{l}\text { Accepted: } \\
\text { 22 October } 2020 \\
\text { Available Online: } \\
10 \text { November } 2020\end{array}$ \\
\hline
\end{tabular}

Study entitled "Line $\times$ Tester analysis in garden pea" was undertaken to estimate the combining ability effects to find out superior cross combinations for their further exploitation. The experimental material comprises of five lines viz., Arka Uttam, IIHR-48, IIHR-34, IIHR-41, Arka Tapas and three testers viz., Arka Ajith, Arka Sampoorna and Arka Priya with their fifteen crosses along with check Arka Pramodh. The parents and hybrids were randomized separately and sown using Randomized Block Design during 2019-20. The results revealed that among the female parent Arka Tapas recorded a significant GCA effect for the most of the yield contributing character except for days taken for first picking. The highest significant desirable SCA effect was observed by the cross Arka Tapas $\times$ Arka Priya for the traits average pod weight (4.03), average green seed weight (2.40), pod yield per plant (16.12), pod yield per hectare (0.91). GCA to SCA ratio was greater than the unity for many of the traits indicating the predominance of additive gene action which can improve through recurrent selection or heterosis breeding.

\section{Introduction}

Garden pea (Pisum sativum L spp. hortense) is a legume crop belonging to the family Leguminosae having a chromosome number of $2 n=14$, which is originated in the Mediterranean region. It is one of the important vegetable having high percentage of protein $(7.2 \mathrm{~g} / 100 \mathrm{~g})$, carbohydrate $(15.8$ $\mathrm{g})$, vitamin-C (9 mg), phosphorus (139 mg), and minerals. The peas which is notably used in the tinned and frozen meals enterprise to deliver the necessary proteins for human nutrition. Moreover, pea contributes to enhancing the yield of succeeding crops in rotation with the aid of enhancing nitrogen content of the soil (Rowland et al., 1994).

Line $\times$ Tester analysis is one of the most powerful tool for predicting the general combining ability (GCA) of parents and selecting suitable parents and crosses with high specific combining ability (SCA) (Rashid et al., 2007). Line $\times$ Tester analysis provides information about combining ability effects of genotypes and also, knowledge 
regarding genetic mechanism controlling yield components. Information of general and specific combining abilities influencing yield and its components has become increasingly important to the plant breeders in order to select appropriate parents for developing hybrid cultivars.

\section{Materials and Methods}

The investigation was carried out at the Department of Vegetable Science, College of Horticulture, Mudigere, University of Agricultural and Horticultural Sciences. Shivamogga during 2019-20. The experimental material consist of five lines viz., Arka Uttam, IIHR-48, IIHR-34, IIHR-41, Arka Tapas and three testers viz., Arka Ajith, Arka Sampoorna and Arka Priya along with their fifteen crosses along with one check Arka Pramodh. The parents, hybrids and check were randomized separately and sown using Randomized Block Design (RCBD) with two replications during 2019-20.Garden pea seeds were sown in each replication with $1.5 \mathrm{~m} \times 1.3 \mathrm{~m}$ plot size at $60 \mathrm{~cm} \times 15 \mathrm{~cm}$ spacing.Observations were recorded on five randomly selected plants in each replication for different traits viz., Days taken for first picking, number of pods per plant, average pod weight $(\mathrm{g})$, pod length $(\mathrm{cm})$, average green seed weight $(\mathrm{g})$, pod width $(\mathrm{mm})$, pod yield (g/plant), pod yield (t/ha), number of seeds per pod, shelling percentage. The data were recorded individually on five randomly selected plants in each replication and their average value was computed.

\section{Results and Discussion}

The ANOVA of combining ability for various characters are presented in Table 1 . The mean sum of squares for crosses was highly significant for all the characters. Whereas, variance due to the lines was highly significant for all the traits. Variance due to the testers was highly significant for character like average pod weight, pod width, pod yield per plant, pod yield per hectare, shelling percentage and remaining character were found to be non-significant.

The mean sum of squares for Line $\times$ Tester interaction was highly significant for all the character except for character days taken for first picking, average green seed weight. This indicates the presence of variability among the treatments. Contribution of the cross variance is higher from the female side than the male for combining ability. Similar findings were also reported by Ceyhan et al., (2008) in garden pea.

The variance of GCA for the parents, SCA for the hybrids and the ratio of the GCA to SCA were presented in table 2. Various character studied from the above investigation stated that out of ten characters studied most of them showed predominance of additive gene action where ratio of GCA to SCA variance greater than the unity similar results are also recorded by Shalaby (1974), Dalia et al., (2013), Sharma et al., (1999) in garden pea. The character number of seeds per pod (0.98) showed a predominance of non-additive gene action, these results are close agreement with the findings of Suman et al., (2017) in garden pea.

\section{General and specific combining effects}

The estimation of general and specific combining ability effects of the parents and hybrids involved in the present investigations are presented in the table 3 and 4 respectively.

For the trait days to first picking, Out of 5 female the highest negative significant effect was recorded in Arka Uttam (-9.63) and the positive significant effect was recorded in IIHR-34 (5.70). 
Table.1 ANOVA for combining ability (GCA) of lines and testers for various characters in garden pea

\begin{tabular}{|l|c|c|c|c|c|}
\hline \multicolumn{1}{|c|}{ Characters } & Replications & \multicolumn{1}{c|}{ Crosses } & Females (Lines) & \multicolumn{1}{c|}{ Males } \\
(Testers)
\end{tabular}

Table.2 Variance due to general combining ability and specific combining ability for different characters in garden pea

\begin{tabular}{|c|l|c|c|c|}
\hline Sl.no. & \multicolumn{1}{|c|}{ Characters } & GCA & SCA & GCA:SCA \\
\hline $\mathbf{1 .}$ & Days taken for first picking & 14.03 & 4.4 & 3.18 \\
\hline $\mathbf{2 .}$ & Number of pods per plant & 0.67 & 0.16 & 4.02 \\
\hline $\mathbf{3 .}$ & Average pod weight $(\mathrm{g})$ & 32.37 & 7.22 & 4.48 \\
\hline $\mathbf{4 .}$ & Pod length (cm) & 0.50 & 0.40 & 1.26 \\
\hline $\mathbf{5 .}$ & Average green seed weight $(\mathrm{g})$ & 11.80 & 2.07 & 5.70 \\
\hline $\mathbf{6 .}$ & Pod width (mm) & 0.31 & 0.07 & 4.07 \\
\hline $\mathbf{7 .}$ & Pod yield (g/plant) & 214.88 & 69.75 & 3.08 \\
\hline $\mathbf{8 .}$ & Pod yield (t/ha) & 1.22 & 0.24 & 4.91 \\
\hline $\mathbf{9 .}$ & Number of seeds per pod & 0.324 & 0.328 & 0.98 \\
\hline $\mathbf{1 0 .}$ & Shelling percentage & 15.38 & 5.38 & 2.85 \\
\hline
\end{tabular}

GCA- General combining ability, SCA- Specific combining ability, DAS - Days after sowing 
Table.3 Estimates of general combining ability (gca) effects of parents for 24 characters in garden pea

\begin{tabular}{|c|c|c|c|c|c|c|c|c|c|c|}
\hline $\begin{array}{l}\text { Traits / } \\
\text { Parents }\end{array}$ & $\begin{array}{c}\text { Days } \\
\text { taken for } \\
\text { first } \\
\text { picking }\end{array}$ & $\begin{array}{c}\text { Number } \\
\text { of pods } \\
\text { per plant }\end{array}$ & $\begin{array}{c}\text { Average } \\
\text { pod weight } \\
\text { (g) }\end{array}$ & $\begin{array}{c}\text { Pod } \\
\text { length } \\
(\mathrm{cm})\end{array}$ & $\begin{array}{c}\text { Average } \\
\text { green seed } \\
\text { weight (g) }\end{array}$ & $\begin{array}{c}\text { Pod } \\
\text { Width } \\
(\mathbf{m m})\end{array}$ & $\begin{array}{c}\text { Pod yield } \\
\text { (g/plant) }\end{array}$ & $\begin{array}{l}\text { Pod yield } \\
\text { (t/ha) }\end{array}$ & $\begin{array}{l}\text { Number of } \\
\text { seeds per } \\
\text { pod }\end{array}$ & $\begin{array}{c}\text { Shelling } \\
\text { percentag } \\
\text { e }\end{array}$ \\
\hline \multicolumn{11}{|c|}{ Females (Lines) } \\
\hline Arka Uttam & $-9.63 * *$ & $0.80 *$ & $-7.36 * *$ & $-0.64 * *$ & $-4.03 * *$ & $-0.43 * *$ & $-17.80^{* *}$ & $-1.41 * *$ & $-0.87 * *$ & $1.94 *$ \\
\hline IIHR-48 & -0.63 & 0.46 & $-8.86 * *$ & $-1.26 * *$ & $-3.20 * *$ & $-0.86 * *$ & $-13.94 * *$ & $-0.99 * *$ & -0.15 & 1.24 \\
\hline IIHR-34 & $5.70 * *$ & $-1.53 * *$ & $3.63 * *$ & 0.18 & $-1.53 * *$ & $-0.26^{*}$ & $-3.98 * *$ & $-0.25^{*}$ & $0.23 *$ & $-6.33 * *$ \\
\hline IIHR-41 & 0.70 & $-1.20 * *$ & 1.13 & $0.30 * *$ & $-1.03 *$ & $0.55 * *$ & -0.273 & -0.03 & $-0.47 * *$ & $-4.13 * *$ \\
\hline Arka Tapas & $3.86^{* *}$ & $1.46 * *$ & $11.46^{* *}$ & $1.42 * *$ & $9.80 * *$ & $1.00 * *$ & $36.00 * *$ & $2.68 * *$ & $1.26^{* *}$ & $7.28 * *$ \\
\hline SEm \pm & 0.67 & 0.27 & 0.63 & 0.10 & 0.42 & 0.12 & 1.10 & 0.08 & 0.10 & 0.85 \\
\hline CD at $5 \%$ & 1.45 & 0.57 & 1.36 & 0.22 & 0.90 & 0.26 & 2.35 & 0.18 & 0.21 & 1.83 \\
\hline CD at $1 \%$ & 2.02 & 0.80 & 1.89 & 0.30 & 1.25 & 0.36 & 3.27 & 0.26 & 0.30 & 2.55 \\
\hline \multicolumn{11}{|c|}{ Males (Testers) } \\
\hline Arka Ajith & -0.16 & -0.25 & $-2.56 * *$ & -0.11 & 0.40 & $-0.29 * *$ & $-8.07 * *$ & $-0.62 * *$ & $-0.370 * *$ & $2.90 * *$ \\
\hline Arka Sampoorna & $-1.26^{*}$ & $0.45^{*}$ & $-1.06^{*}$ & $0.38 * *$ & -0.50 & -0.16 & -0.73 & -0.05 & 0.010 & -0.08 \\
\hline Arka Priya & $1.43 *$ & -0.20 & $3.63 * *$ & $0.49 * *$ & 0.10 & $0.46 * *$ & $8.81 * *$ & $0.67 * *$ & $0.360 * *$ & $-2.81 * *$ \\
\hline SEm \pm & 0.52 & 0.20 & 0.49 & 0.08 & 0.32 & 0.09 & 0.85 & 0.06 & 0.07 & 0.66 \\
\hline CD at $5 \%$ & 1.12 & 0.44 & 1.05 & 0.17 & 0.70 & 0.20 & 1.82 & 0.14 & 0.16 & 1.42 \\
\hline CD at $1 \%$ & 1.56 & 0.62 & 1.46 & 0.23 & 0.97 & 0.28 & 2.53 & 0.20 & 0.23 & 1.97 \\
\hline
\end{tabular}


Table.4 Estimates of specific combining ability (sca) effects for various characters in 15 garden pea hybrids

\begin{tabular}{|c|c|c|c|c|c|c|c|c|c|c|}
\hline $\begin{array}{l}\text { Traits / } \\
\text { Crosses }\end{array}$ & $\begin{array}{c}\text { Days taken } \\
\text { for first } \\
\text { picking }\end{array}$ & $\begin{array}{c}\text { Number of } \\
\text { pods per } \\
\text { plant }\end{array}$ & $\begin{array}{c}\text { Average } \\
\text { pod weight } \\
(\mathrm{g})\end{array}$ & $\begin{array}{l}\text { Pod length } \\
\quad(\mathrm{cm})\end{array}$ & $\begin{array}{c}\text { Average } \\
\text { green seed } \\
\text { weight (g) }\end{array}$ & $\begin{array}{c}\text { Pod } \\
\text { width } \\
(\mathrm{mm})\end{array}$ & $\begin{array}{c}\text { Pod yield } \\
\text { (g/plant) }\end{array}$ & $\begin{array}{l}\text { Pod yield } \\
\text { (t/ha) }\end{array}$ & $\begin{array}{l}\text { Number of } \\
\text { seeds per } \\
\text { pod }\end{array}$ & $\begin{array}{c}\text { Shelling } \\
\text { percentage }\end{array}$ \\
\hline Arka Uttam $\times$ Arka Ajith & 1.33 & 0.5 & 0.56 & $-0.45^{*}$ & -0.06 & -0.27 & 5.79 & 0.27 & $-0.63 * *$ & -2.69 \\
\hline $\begin{array}{l}\text { Arka Uttam } \times \text { Arka } \\
\text { Sampoorna }\end{array}$ & $-2.56 *$ & 0.3 & -1.93 & $-0.67 * *$ & 0.33 & 0.33 & -2.69 & -0.001 & -0.21 & $3.83 *$ \\
\hline Arka Uttam $\times$ Arka Priya & 1.23 & -0.8 & 1.36 & $1.12 * *$ & -0.26 & -0.06 & -3.09 & -0.27 & $0.84 * *$ & -1.14 \\
\hline IIHR-48 × Arka Ajith & 0.33 & -0.41 & $3.06^{*}$ & 0.15 & 1.1 & 0.22 & 3.18 & 0.09 & -0.04 & -1.41 \\
\hline IIHR-48 × Arka Sampoorna & 0.93 & -0.11 & 0.06 & -0.33 & -0.5 & -0.02 & 2.41 & 0.15 & 0.17 & 1.02 \\
\hline IIHR-48 $\times$ Arka Priya & -1.26 & 0.53 & $-3.13 *$ & 0.18 & -0.6 & -0.19 & $-5.60 *$ & $-0.24 *$ & -0.12 & 0.39 \\
\hline IIHR-34 × Arka Ajith & -0.5 & 0.58 & -1.93 & -0.25 & 0.43 & -0.01 & $3.42 *$ & $0.41 *$ & -0.03 & 1.51 \\
\hline $\begin{array}{l}\text { IIHR-34 × Arka } \\
\text { Sampoorna }\end{array}$ & 1.6 & -0.11 & $3.06^{*}$ & $0.52 *$ & 0.33 & -0.08 & 3.15 & -0.09 & -0.31 & -1.81 \\
\hline IIHR-34 $\times$ Arka Priya & -1.1 & -0.46 & -1.13 & -0.27 & -0.76 & 0.09 & $-6.57 * *$ & -0.31 & 0.34 & 0.29 \\
\hline IIHR-41 × Arka Ajith & -0.5 & -0.75 & 1.06 & $0.43^{*}$ & -0.06 & $0.49 *$ & -0.31 & 0.10 & $0.47^{*}$ & -1.23 \\
\hline IIHR-41 x Arka Sampoorna & 0.6 & 0.05 & 0.06 & 0.3 & 0.83 & -0.37 & 1.16 & -0.02 & $0.49 *$ & 0.30 \\
\hline IIHR-41 × Arka Priya & -0.1 & 0.7 & -1.13 & $-0.72 * *$ & -0.76 & -0.12 & -0.85 & -0.08 & $0.96 * *$ & 0.92 \\
\hline Arka Tapas $\times$ Arka Ajith & -0.66 & 0.08 & $-2.76 *$ & 0.12 & -1.4 & -0.42 & $-12.08 * *$ & $-0.88 * *$ & 0.23 & $3.83 *$ \\
\hline $\begin{array}{l}\text { Arka Tapas } \times \text { Arka } \\
\text { Sampoorna }\end{array}$ & -0.56 & -0.11 & -1.26 & 0.18 & -1 & 0.14 & -4.03 & -0.03 & -0.14 & $-3.35^{*}$ \\
\hline Arka Tapas $\times$ Arka Priya & 1.23 & 0.03 & $4.03 * *$ & -0.31 & $2.40 * *$ & 0.28 & $16.12 * *$ & $0.91 * *$ & -0.09 & -0.48 \\
\hline SEm \pm & 1.17 & 0.46 & 1.10 & 0.17 & 0.73 & 0.21 & 1.90 & 0.15 & 0.17 & 1.48 \\
\hline $\mathrm{CD}$ at $5 \%$ & 2.52 & 1.0 & 2.36 & 0.38 & 1.56 & 0.45 & 4.08 & 0.32 & 0.37 & 3.18 \\
\hline CD at $1 \%$ & 3.50 & 1.39 & 3.28 & 0.53 & 2.17 & 0.63 & 5.67 & 0.45 & 0.52 & 4.42 \\
\hline
\end{tabular}

$*$ and ** indicates Significant at $5 \%$ and $1 \%$ level respectively. DAS - Days after sowing 
Among the male parent highest negative significant effect was observed in the tester Arka Sampoorna (-1.26). Out of 15 hybrids, the maximum significant negative SCA effect was evidenced in the hybrid i.e. Arka Uttam $\times$ Arka Sampoorna (-2.56) which is considered as a good specific combiner for this trait. The above results are in accordance with the findings Hasan et al.(2004) and Kwaye et al., (2008) in garden pea.

Significant GCA effects for the trait number of pods per plant was observed by the parents Arka Tapas (1.46) followed by Arka Uttam (0.80). Among the testers Arka Sampoorna (0.45) showed significant positive GCA effect.

The extent of SCA in desirable direction was found in the cross IIHR-34 $\times$ Arka Ajith (0.58) and none of the hybrid showed significant positive SCA effect for this trait. The present results endured sheikh et al., (2015) in garden pea.

For the character Average pod weight line Arka Tapas (11.46) being highest followed by IIHR-34 (3.63) and in case of testers, Arka Priya (3.63) disclosed significant GCA effect and act as a good general combiner. The significant positive SCA effect was observed in the cross Arka Tapas $\times$ Arka Priya (4.03) followed by IIHR-48 $\times$ Arka Ajith and IIHR$34 \times$ Arka Sampoorna (3.06) and act as a good specific combiner. These results are similar to the findings of Dalia et al., (2013) in garden pea.

The good general combiner among parents for the trait pod length in line Arka Tapas (1.42) and tester Arka Priya (0.49) has a high positive GCA effect and among the 15 hybrids studied the cross Arka Uttam $\times$ Arka Priya (1.12) followed by IIHR-34 $\times$ Arka Sampoorna (0.52) recorded a maximum significant SCA effect and act as a best general combiner. Similar findings were recorded by Nageshwar et al., (2018), Venkateswarlu and Singh (1982) in garden pea.

The line Arka Tapas (9.80) were designated as a good general combiner and exhibited positive general combining ability effect for the trait average green seed weight in desirable direction, in the other hand the maximum significant positive SCA effect was exhibited by the cross Arka Tapas $\times$ Arka Priya (2.40). These results are in close agreement with the findings of Hama-Amin (2019), Hasan et al., (2004) in garden pea.

The parental line Arka Tapas (1.00) followed by IIHR-41 (0.55) were the good general combiner and indicating the presence of the positive GCA effect in positive direction. At the same time hybrid IIHR-41 $\times$ Arka Ajith (0.49) found to be good specific combiner and showed significant positive SCA effect in desirable direction for the character pod width and indicating the role of the additive gene action, these results were in agreement with the findings of several workers to quote some of them are Shalaby (1974), Dalia et al., (2013) in garden pea.

Both Pod yield per plant and pod yield per hectare in the garden pea showed a significant positive GCA effect in desirable direction, out of the 8 parents studied the line Arka Tapas (36.00 and 2.68) exhibited a highest positive GCA effect, similarly out of 15 crosses cross Arka Tapas $\times$ Arka Priya (16.12 and 0.91) followed byIIHR-34 $\times$ Arka Ajith (3.42 and 0.41 ) displayed maximum significant SCA effect and act as a good specific combiner. Above results were agreement with the findings of Singh et al., (1994)and Sharma et $a l .$, (1999) in garden pea

For number of seeds per pod the parents Arka Tapas (1.26), IIHR-34 (0.23) exhibited a 
maximum significant GCA effect. Significant SCA effect is also showed by the 4 hybrids out of which highest significant SCA effect is recorded by the hybrid IIHR-41 $\times$ Arka Priya (0.96) followed by Arka Uttam $\times$ Arka Priya ( 0.84 ) act as a good specific combiner. Number of hybrids showed significant SCA effect for number of seeds per pod suggested the inheritance of this trait is mainly because of the non-additive gene action. Similar observations were also made byKumar et al., (1996), Singh and Singh (1978), Ceyhan et al., (2008) and Suman et al., (2017) in garden pea.

Among the parents, line Arka Tapas (7.28), Arka Uttam (1.94) and the tester Arka Ajith (2.90) considered as a good general combiner and showed high significant GCA effect for the trait shelling percentage, similarly the significant positive SCA effect was exhibited by the hybrids Arka Tapas $\times$ Arka Sampoorna and Arka Uttam $\times$ Arka Sampoorna (3.83) act as a best specific combiner, these findings are inconsonance with the reports of Brar et al., (2012) in garden pea.

From the above experiment it is concluded that among the parents the line Arka Tapas identified as a good general combiner for most of the character like Number of pods per plant, average pod weight $(\mathrm{g})$, pod length $(\mathrm{cm})$, average green seed weight $(\mathrm{g})$, pod width (mm), pod yield (g/plant), pod yield ( $\mathrm{t} / \mathrm{ha}$ ), number of seeds per pod, shelling percentage and the tester Arka Priya for the traits Average pod weight (g), pod length (cm), pod width $(\mathrm{mm})$, pod yield (g/plant), pod yield ( $\mathrm{t} / \mathrm{ha})$, number of seeds per pod.

The cross Arka Tapas $\times$ Arka Priya was best specific cross combination for the traits Average pod weight (g), average green seed weight (g), pod yield (g/plant), pod yield (t/ha) and Arka Uttam $\times$ Arka Sampoorna for days taken for first picking.

\section{References}

Brar, P.S., Dhall, R.K. and Dinesh, 2012. Heterosis and combining ability in garden pea (Pisum sativum L.) for yield and its contributing traits. Vegtable Science. 39(1): 51-54.

Ceyhan, E., Avci, M. A. and Karadas, S. 2008. Line $\times$ tester analysis in pea (Pisum sativum L.). Identification of superior parents for seed yield and its components. African Journal of Biotechnology. 7: 2810-281.

Dalia, M.T. and El-Rawy, M.A. 2013. Analysis of Gene Effects Controlling Some Traits in Garden Pea (Pisum Sativum L.). Australian Journal of Basic and Applied Science. 7(1): 537-542.

Hama-Amin T. N. 2019. Half diallel analysis of seven pea cultivars for seed yield and its components for $\mathrm{F} 4$ generation under sulaimani condition. Iraqi Journal of Agriculture Science. 51(2): 600-610.

Hasan Mitu, M.K., Islam, A.K., Ahmed and Mian, M.A. 2004. Combining ability for yield-related characters in pea (Pisum sativum L.). B $\mathrm{S}$ M R Agriculture University, Gazipur. Bangladesh.

Kwaye, G., Shimelis Hussein and William, P. 2008. Combining ability analysis and association of yield and yield components among selected cowpea lines. Euphytica.16: 205-210.

Nageshwar, Bijendra Kumar, Hariom Suman, A.H., Madakemohekar and Dattesh Tamatam, 2018. Combining ability and Heterosis analysis for grain yield and yield associated traits in Pea (Pisum sativum L.). Legume Research. 64: 1-7

Rashid, M.A., Cheema and M. Ashraf, 2007. LinexTester analysis in basmati rice. Pakistan Journal of Botany. 39(6): 2035-2042.

Rowland, I., Mason, M., Pritchard, I and French, R. 1994. Effect of field peas 
and wheat on the yield and protein of subsequent wheat crops grown at several rates of applied nitrogen. Australian Journal of Experiment Agriculture. 34: 641-46.

Shalaby, G. I. 1974. Estimates of genetic and environmental variability in some cultivars of pea (Pisum sativum L.). Assiut Journal of Agricultural Sciences. 5(2): 65-72.

Sharma, D.K., Adarsh Bala and Chaudhary, D.R. 1999. Studies on combining ability and gene action in pea (Pisum sativum L). Indian Journal of Hill Farming. 12(1): 32-36.

Sheikh, M.A., Marawar, M.W., Ingle, A.U. and Gedam S.R. 2015. Heterosis studies for grain yield in pea (Pisum sativum L.). Trends in Biosciences. 8(13): 3497-3502.
Singh, S.P., Singh, H.N., Singh, N.D. and Srivatsava, J.P. 1978. Heterosis in peas. Indian Journal of Agriculture. 48: 705710 .

Singh, V.P., Pathak, M.M. and Singh, R.P. 1994. Combining ability in pea. Indian Journal of Pulses Research. 7: 11-14.

Suman, H., Bijendra Kumar, Nageshwar, Meenakshi Rathi and Dattesh Tamatam, 2017. Heterosis and combining Ability for grain yield and yield associated traits in $10 \times 10$ Diallel analysis in Pea (Pisum sativum L.). International Journal of Current Microbiology and Applied Sciences.6(12): 1574-1585.

Venkateswaralu, S. and Singh, R. B. 1982. Inheritance of seed number and seed weight in pea. Journal of Genetics. 42: 20-22.

\section{How to cite this article:}

Manjunath, B., Devaraju, V. Srinivasa, M. Hanumantappa, D. Lakshmana, and Aghora, T. S. 2020. Combining Ability Studies for Yield and Yield Contributing Traits in Garden Pea (Pisum sativum L.). Int.J.Curr.Microbiol.App.Sci. 9(11): 3261-3268.

doi: https://doi.org/10.20546/ijcmas.2020.911.391 